\title{
Potential of acha (Digitaria spp.) grains as feedstuff for chicken diets in the wake of Covid-19 pandemic challenges: A review
}

${ }^{1}$ Ukim, C. I., ${ }^{2}$ Ndelekwute, E. K. ${ }^{3}$ Kennedy, O. O., ${ }^{3}$ Ayuk, A. A. and ${ }^{3}$ Agwunobi, L. N.

${ }^{I}$ Department of Research and Development/Centre for Excellence, Tertiary Education Trustfund, Abuja, Nigeria

${ }^{2}$ Department of Animal Science, University of Uyo, Uyo, Nigeria

${ }^{3}$ Department of Animal Science, University of Calabar, Calabar, Nigeria

*Corresponding author: ndelekwute.ek@gmail.com;+2348061220967.

\section{Abstract}

$\overline{\text { Current fall in supply offeedstuff and high price offeed ingredients is mainly due to Covid-19 }}$ pandemic which has put farmers out of farms. Maize, sorghum and millet the major cereal grains used in poultry feed production have become more expensive and strategies need to be adopted to ameliorate this. Hence a review study was carried out to unravel the potentials of acha grains as a feedstuff which is in the class of maize in poultry feeds. Acha is a tiny cereal grain grown in Northern part of Nigeria which is not popular in poultry feeds. Its starch content (80\%) is high, low crude fibre (1.0\%), appreciable level of lysine (more than $1.0 \%$ ) and methionine (0.40\%) and higher metabolizable energy (3700 Kcal_ME/kg) compared to maize. Its nutrient digestibility is high in terms of starch, crude protein and crude fibre. Though acha contains anti-nutritional factors such as tannins, saponin and phytic acid, the levels of the anti-nutritional factors are comparable to maize and are tolerated by chickens. Both the polished and unpolished acha grains could be used in place of maize, sorghum and millet. With vast area of land in Northern part of Nigeria, production and supply of acha to feed millers could be sustained, which could lead to a reduction in the price of maize and improved profit maximization by farmers.

Keywords: Acha, Cereal grains, Covid-19, Feed for poultry

\section{Potentiel des céréales acha (Digitaria spp.) Comme aliment pour l'alimentation des poulets à la suite des défis de la pandémie de Covid-19: Un examen}

\section{Résumé}

La baisse actuelle de l'offre d'aliments pour animaux et le prix élevé des ingrédients alimentaires sont principalement dus à la pandémie de Covid-19 qui a poussé les agriculteurs à quitter les fermes. Le maïs, le sorgho et le millet, les principales céréales utilisées dans la production d'aliments pour la volaille, sont devenues plus chères et des stratégies doivent être adoptées pour y remédier. Par conséquent, une étude de revue a été menée pour démêler le potentiel des grains d'acha en tant qu'aliment qui appartient à la classe du maïs dans les aliments pour volaille. Acha est une minuscule céréale cultivée dans la partie nord du Nigéria qui n'est pas populaire dans les aliments pour volaille. Sa teneur en amidon (80\%) est élevée, faible en fibres brutes (1,0\%), un niveau appréciable de lysine (plus de 1,0\%) et de méthionine (0,40\%) et une énergie métabolisable plus élevée (3700 Kcal_ME/ $\mathrm{kg})$ par rapport au maïs. Sa digestibilité des nutriments est élevée en termes d'amidon, de protéines brutes et de fibres brutes. Bien que l'acha contienne des facteurs antinutritionnels tels que les tanins, la saponine et l'acide phytique, les niveaux des facteurs antinutritionnels sont comparables à ceux du maïs et sont tolérés par les poulets. Les grains d'acha polis et non polis peuvent être utilisés à la place du maïs, du sorgho et du millet. Avec une vaste superficie de terres dans la partie nord du Nigéria, la production et la fourniture d'acha aux meuniers 


\section{Importance of acha as a potential feedstuff in Covid-19 era}

pourraient être soutenues, ce qui pourrait entraîner une réduction du prix du maïs et une meilleure maximisation des profits par les agriculteurs.

Mots clés: Acha, Céréales, Covid-19, Aliments pour volailles.

\section{Introduction}

The advent of Covid-19 had led to sharp fall in agricultural activities and invariably the production of grains especially maize, sorghum and millet used to produce poultry feeds worldwide. Covid-19 is a viral disease first reported in China which gradually spread globally becoming a pandemic (WHO, 2019). According to official reports it is highly infectious and lethal with countries such as France, Italy, Brazil and United States of America recording high mortalities (WHO, 2019). As it spreads, countries adopted travel restrictions and bans. At a stage nations imposed total lockdown including Nigeria. This led to sharp fall in economic and agricultural activities and its negative impact on poultry production is overwhelming. Despite the fact that the entire world is united to fight the pandemic, its negative effect is still forging and it is of great concern to leaders, citizens, and livestock farmers' world over. Since then prices of cereal grains (maize, sorghum and millet) which account for larger portion of poultry feeds (Olomu, 2011) and other feed ingredients have sky rocketed. Thus prices of poultry feed which form over $70 \%$ of cost of poultry production had soared. To minimize cost and maximize profit, the use of these conventional cereal grains had become infeasible. Farmers and nutritionists should look outside the conventional grains and try to integrate nonconventional grains that are nutritionally promising with potentials to ameliorate this. Acha spp could be a good candidate for this. Acha is a cereal, which grows well in Nigeria and is a staple food in some parts of Nigeria and across some west and north African countries (Jideani, 1999). Its grains are smaller than the grains of rice (Jideani
1999). It is indigenous to the savannah regions of West Africa (Purseglove, 1988) and belongs to the family Graminae and genus digitaria. There are about 300 annual and perennial species, most of which are important pasture grasses, as such, can as well be easily mistaken for pasture grass (Jideani, 1999). It closely resembles the wild Digitaria longiflora (Retz) and grows under varying conditions from poor dry upland soils to hydromorphic valleys suitable for rice production (Purseglove, 1988). Its nutritional value and potential as feed ingredient and the need to revamp and increase its production in Africa have been stressed (NRC, 1996). Therefore, the objective of this study was to review the nutritional quality and potential of acha as feed ingredient in this era of Covid-19.

\section{Origin and distribution of acha}

Acha (Digitaria spp.) which is also known with other names such as fonio, iburu, findi, fundi, pom and kabug in different West African countries has been reported to be the oldest West African cereal, since its cultivation is thought to date back to 5000 BC (NRC, 1996), or 7000 years ago (Cruz, 2004). The Europeans because acha was used by rural poor people apart from conventional grains such as maize and rice coined the English name "Hungry rice" (Ibrahim, 2001). There are over 300 Digitaria species but only three or four species are grown as cereals while most of the species are grown as fodder (CIRAD, 2004). The two main varieties majorly cultivated are Digitaria exilis or white acha and Digitaria iburua called black acha (Philip and Isaac, 2012). According to Philip and Isaac (2012) about 70 percent of farmers cultivate the white acha while 6 percent cultivate the black acha and 24 percent grow both species. The preference 
to cultivate the white acha include higher yield, easy dehulling process, availability of planting materials, preference by consumers, early maturity and adaptation (Philip and Isaac, 2012). The preference by human for white acha has given room for the production of black acha for livestock consumption.

Statistics from FAO (2003) indicated that a total area of 347,380 hectares was dedicated to acha production in Africa in 2002, with Nigeria alone producing half of the total area. In West Africa, acha is produced annually on an area of about 380,000 hectares with an estimated output of 250,000 tonnes (Cruz, 2004). Reports have put the annual output of acha to be 3,098126,000 metric tonnes (Abdullahi and Luka, 2003). Also, Gyang and Wuyep (2005) reported that acha is grown in commercial quantity in various parts of Nigeria, citing Plateau State as the largest producer with an estimated production of 20,000 tonnes per annum.

\section{Acha production in Nigeria}

In a study, Dachi and Gana (2008) reported that acha can be cultivated two to three times a year since it matures within an average of 120 days. Among the West African countries, the most leading producing countries of acha are Nigeria, Guinea, Burkina Faso and Mali. Annual production in West Africa is estimated at about 250,000 tonnes (Cruz, 2004). The global land area being put to its production is estimated to be 380,000 hectares with an annual production of 250,000 tonnes (Cruz, 2004). The average production of acha per hectare has remained low ranging from 600$700 \mathrm{~kg} / \mathrm{ha}$ (Cruz, 2004). Dachi and Omueti (2000) also reported that acha responds positively to fertilizer application. Acha is one of the world's fastest maturing cereals with the production of grains at $42-56$ days after planting for the early varieties (Ibrahim, 2001) and 150 days for late maturing varieties (CIRAD, 2006). Philip and Isaac (2012) reported that acha production and processing have been at a zero mechanization level and no proper research effort has been carried out towards its mechanization in Nigeria. Also, Philip and Isaac (2012) noted that there are no machines for planting, harvesting, threshing and dehulling of the crop on Nigerian farms. The competitiveness of acha has to be addressed through the provision of appropriate information and technologies that can support mass production, so as to be able to bring the crop to prominence (Philip and Isaac, 2012).

\section{Nutrient composition of acha grains}

There are marked variations in nutrient composition of acha grains which was attributed to environmental influences, geographical location, agronomic and genetic factors, and different analytical methods (Ballogou et al., 2013). The major constituents of cereals are carbohydrate and protein. Acha is the most nutritious cereals and a good source of cysteine and methionine, which are important to the health of humans and growth of poultry, which are not readily found in most cereals. In a study conducted by Chukwu and Abdul-Kadir (2008) on the proximate and chemical composition of acha to determine the content amino acids and essential minerals, it was found that acha contained more methionine and some essential minerals and trace elements, like, calcium, magnesium, iron and copper than most cereals.

\section{Crude protein content of acha}

Acha has high protein content which is on the average is more than $7 \%$ and is found to be rich in leucine, valine and methionine, and the grain has been regarded as best nutritious and tasty of all grains (Kuta et al., 2005). Idris et al. (2015) investigated and compared the nutritive value of black and white acha using standard procedures. The report showed that black acha contained high values for protein, fat, crude fiber and energy than white acha (Table 1). 
Importance of acha as a potential feedstuff in Covid-19 era

Table 1 : Nutrients composition (\%) of black and white acha grains

\begin{tabular}{lll}
\hline Nutrients & Black acha & White acha \\
\hline Protein & 8.75 & 7.11 \\
Fat & 4.00 & 3.00 \\
Crude fibre & 1.03 & 0.79 \\
Carbohydrate & 76.91 & 79.72 \\
Ash & 2.31 & 2.13 \\
Moisture & 7.00 & 7.00 \\
Gross energy $(\mathrm{Kcal} / 100 \mathrm{~g})$ & 378.64 & 374.32 \\
Minerals & & \\
Sodium & 30.00 & 20.00 \\
Potassium & 8.45 & 5.40 \\
Calcium & 30.00 & 20.00 \\
Iron & 2.75 & 1.10 \\
Zinc & 0.75 & 0.65 \\
\hline Source & &
\end{tabular}

Source: Idris et al. (2015).

The protein content of acha grains ranges from 7.0 - 11.5 percent as reported by Chukwu and Abdul-Kadir (2008), Anuonye et al. (2010), Cruz et al. (2011) and Idris et al. (2015). Crude protein content in some polished acha genotypes ranges from 3.75 7.75 percent (Parr et al.,1988) while the unpolished acha grains contain more crude protein of about 11.8percent (Chukwu and Abdul-kadir, 2008).

In determining the amino acid composition of acha grains, Chukwu and Abdul-Kadir (2008) reported the presence of phenylalanine, histidine, isoleucine, leucine, lysine, methionine, threonine, tryptophan and valine (Table 3). Lysine has been found to be deficient in acha grains protein like in most cereals (Chukwu and Abdul-Kadir, 2008). Acha is very rich in methionine and cysteine the two humanvital amino acids almost deficient in the major cereals like maize, sorghum, wheat and barley (Fliedel et al., 2004).

Carbohydrate is the major component in cereals and constitutes the main energy source used by humans and livestock. Carbohydrate forms the basis of many industries in the food and feed sectors and also provide renewable and environmentally friendly raw materials for industrial applications. These include biodegradable plastics, adhesives and ethanol-based fuels. The carbohydrate content in acha grains varied from 67.1 to 91.0 percent (Echendu et al., 2009; Idris et al., 2015)

\section{Energy content of acha}

There is not much literature on the energy value of acha grains, though from investigation by Jideani and Akingbala (1993) it was found that acha grains contained $4619 \mathrm{KcalGE} / / \mathrm{Kg}$ (Table 2). This result was higher than that reported by Serna-Saldivar (2003) for other cereals like maize (4043 KcalGE/Kg), sorghum ( $3868 \mathrm{Kc}$ a l GE/Kg and rice (4307KcalGE/Kg). Studies conducted by Ukim et al. (2013) and later Idris et al. (2015) showed metabolizable energy content of acha to be $3556.06 \mathrm{Kcal} / \mathrm{kg}$ and $374.32 \mathrm{Kcal} / 100 \mathrm{~g}$ respectively. These values are higher than the value of maize $(3300 \mathrm{Kcal} / \mathrm{kg})$ reported by Davis et al. (2003). Studies conducted by Ukim et al. (2013) and later Idris et al. (2015) showed metabolizable energy content of acha to be $3556.06 \mathrm{Kcal} / \mathrm{kg}$ and $374.32 \mathrm{Kcal} / 100 \mathrm{~g}$ respectively. These values are higher than the value of maize $(3300 \mathrm{Kcal} / \mathrm{kg})$ reported by Davis et al. (2003).

\section{Crude fibre content of ach a grains}

Fibres are fraction of consumed food, which 
Ukim, Ndelekwute, Kennedy, Ayuk and Agwunobi

are poorly degraded in the gut of poultry and swine. This constitute cellulose (acid detergent fibre), hemicellulose (neutral detergent fibre) and lignin (acid detergent lignin) which are polysaccharides (McDonald et al., 2000; Idris et al., 2015). Echendu et al. (2009) and Idris et al. (2015) reported that polished acha contains 1.03 and $1.78 \%$ of crude fibre and unpolished grains contain 11.30 percent (Serna -Saldivar, 2003). Though the unpolished type of acha contains higher crude fibre, it is more digestible compared to crude fibre in maize (Ukim et al., 2020).

\section{Fat content of ach a grains}

Fats are slightly low in cereal grains, although they are significant in livestock nutrition as energy source and essential fatty acids. The fat contents reported for acha grains varied from $1.3-5.2 \%$ with a mean value of $3.25 \%$ (Table 2). SernaSaldivar (2003) reported that the mean value obtained for acha grains are comparable to the average fat contents reported for sorghum (3.2\%) millet (5.1\%) and rice $(2.5 \%)$.

Table 2: Proximate composition of acha grains

\begin{tabular}{llll}
\hline Composition & $\begin{array}{l}\text { Acha } \\
\text { Min }\end{array}$ & Average & Max \\
\hline Energy (KCalME/Kg) & 3868 & 4244 & 4619 \\
Carbohydrates (\%) & 67.10 & 79.05 & 91.00 \\
Protein (\%) & 5.10 & 8.05 & 11.00 \\
Crude Fiber (\%) & 0.41 & 5.85 & 11.30 \\
Fat (\%) & 1.30 & 3.25 & 5.20 \\
Ash (\%) & 1.00 & 3.50 & 6.00 \\
\hline
\end{tabular}

Sources: Jideani and Akingbala (1993), Serna-Saldivar (2003),

Ballogou et al. (2013), Ukim et al. (2018)

Table 3: Amino acid composition of acha grains

\begin{tabular}{llll}
\hline Amino acid (\%) & Min. & Average & Max. \\
\hline Essential & & & \\
Phenylalanine & 2.34 & 3.72 & 5.10 \\
Histidine & 1.33 & 1.71 & 2.10 \\
Isoleucine & 1.37 & 2.68 & 4.00 \\
Leucine & 4.40 & 7.10 & 9.80 \\
Lysine & 1.90 & 2.25 & 2.60 \\
Methionine & 0.30 & 0.43 & 0.56 \\
Threonine & 1.89 & 2.94 & 4.00 \\
Tryptophan & 0.90 & 0.92 & 0.95 \\
Valine & 2.34 & 4.07 & 5.80 \\
Non-essential & & & \\
Aspartic acid & 3.50 & 5.00 & 6.50 \\
Glutamic acid & 6.90 & 13.55 & 20.20 \\
Alanine & 4.20 & 6.60 & 9.00 \\
Arginine & 1.30 & 2.55 & 3.80 \\
Cysteine & 2.80 & 2.90 & 3.00 \\
Glycine & 1.90 & 2.55 & 3.20 \\
Proline & 3.20 & 5.15 & 7.10 \\
Serine & 2.10 & 3.60 & 5.10 \\
Tyrosine & 0.91 & 2.25 & 3.60 \\
\hline S & & & \\
\hline
\end{tabular}

Sources: Chukwu and Abdul-kadir (2008), Ukim et al. (2018) 
Importance of acha as a potential feedstuff in Covid-19 era

Table 4: Min eral composition of acha grains

\begin{tabular}{llll}
\hline Minerals & Min. & Average & Max. \\
\hline Macro elements (\%) & & & \\
Calcium (Ca) & 0.0067 & 0.018 & 0.03 \\
Phosphorus (P) & 0.09 & 0.17 & 0.25 \\
Potassium (K) & 0.02 & 0.14 & 0.26 \\
Sodium (Na) & 0.005 & 0.017 & 0.03 \\
Magnesium (Mg) & 0.07 & 0.46 & 0.85 \\
Sulphur (S) & - & 0.16 & - \\
Microelements (ppm) & 36 & & \\
Iron (Fe) & 1.5 & 84.8 & 134 \\
Copper (Cu) & 21.6 & 8.25 & 15 \\
Manganese (Mn) & 30 & 25.8 & 30 \\
Zinc (Zn) & 36.15 & 42.3 \\
\hline
\end{tabular}

Sources: Fliedel et al. (2004), Chukwu and Abdul-Kadir (2008), Cruz et al. (2011).

\section{Mineral composition of ach a grains}

Jideani and Akingbala (1993) and SernaSaldivar (2003) reported that acha grains contained $1-6 \%$ ash. The major mineral elements found in acha grains are magnesium, phosphorus and potassium. Ballogou et al. (2013) revealed that calcium content of acha ranged from $0.0067-0.03$ $\%$, phosphorus $0.09-0.25 \%$, potassium $0.02-0.26 \%$ while sodium $0.005-0.03 \%$. Also, magnesium content ranged from 0.07 - $0.85 \%$, sulphur $0.16 \%$, and iron was 36 133.6 ppm, copper 1.5 - 15 ppm, manganese 21.6 - 30 ppm and zinc 30 - 42.3 ppm (Table 4). Phosphorus in acha grain is quite high as the grains can provide much of the phosphorus requirements in animal diets (Ballogou et al., 2013). Also, the amount of potassium though not high in acha grains, can meet some of the requirements needed for the formulation of poultry feeds (Clottey 2006). Acha grain is also rich in trace minerals which can provide adequately the trace minerals needs of poultry (Clottey, 2006).

\section{Anti-nutritional factors in acha grains}

A major constraint to the use of plant grains and other non-conventional feed ingredients is the composition of naturally occurring toxic substances in those grains. These substances known as anti-nutritional factors (ANFs) depress poultry performance. Anti-nutritional factors (ANFs) as defined by Aganga and Tshwenyane (2003) are those substances generated in natural feedstuffs, which interfere with the digestive process or metabolic utilization of feed and exert effects contrary to optimum nutrition. Acha grains have been reported to contain some anti-nutritional components such as trypsin inhibitors, tannins, phytate, oxalate, hydrogen cyanide and traces of saponins and oxalate (Echendu et al. 2009; Anuonye et al. 2010). Study conducted by Echendu et al. (2009) revealed the presence of trypsin inhibitors $(38.45 \mathrm{mg} / 100 \mathrm{~g})$ in acha grains. Trypsin inhibitors interfere with normal protein digestion in the intestinal tract and lead to an enlargement of the pancreas in chickens and rats. Tannins as defined by Mitaru et al. (1984) are water-soluble phenolic compounds, widely distributed in the plant kingdom and have very high protein binding capacity. Like other ANFs, ingestion of tannins below 1.30 percent concentrations has been reported to be tolerated by chicks (Jansman et al., 1989) and above this concentration, it reduced daily weight gain and impaired feed efficiency due to decrease in digestibility of protein in chickens (Olomu, 2011). Tannins form tannin - protein complexes which are partly responsible for low protein 


\section{Ukim, Ndelekwute, Kennedy, Ayuk and Agwunobi}

digestibility and low amino acid availability and thus increased faecal nitrogen excretion in chickens (Ortiz et al. 1993). Echendu et al. (2009) reported tannins content of acha grain as $0.13 \mathrm{mg} / 100 \mathrm{~g}$. Tannins have been reported to adversely affect feed intake, feed efficiency, dry matter and protein digestibility in broiler chickens (Knox and $\mathrm{McNab}, 1995)$. In cereal grains byproducts and oil seed meals, about $60-70 \%$ of the phosphorus is originally bond as phytate or phytic acid (NRC, 1996) which is poorly available to poultry and swine. Phytic acid is hexa-phosphate ester of inositol which can form complexes with divalent cations and thereby reduces the bioavailability of certain minerals like calcium, copper, iron, magnesium and zinc (Echendu et al., 2009). Also Echendu et al. (2009) reported phytate values of $1.22 \mathrm{mg} / 100 \mathrm{~g}$ in acha grains and Anounye et al. (2010) reported that phytate content of acha grains is comparable to other conventional legumes like soybean and cowpea (Hidvegi and Lasztity, 2002). The digestibility of phytic acid is dependent on the enzyme, phytase, which tends to be lacking in poultry. This could be overcome by addition of feed grade phytase to the feed. Oxalates are poorly soluble at intestinal $\mathrm{pH}$ and oxalic acid is known to decrease calcium absorption in monogastric animals (Echendu et al., 2009). Echendu et al. (2009) reported oxalate value of
$1.14 \mathrm{mg} / 100 \mathrm{~g}$ in acha grain. Oxalate binds to calcium to form complexes (calcium oxalate crystals). These oxalate crystals when formed, prevent the absorption and utilization of calcium by the body causing diseases such as rickets and osteomalacia (Ladeji et al. 2004). The level of each antinutritional factor contained in acha indicates that they could be tolerated by poultry (Jideani, 1999). Collaborating this, Ukim et al. (2018) noted that feeding acha to broiler chickens did not impart negatively on the pathology of their liver.

Nutrient contents in acha compared to some cereal grains

The nutrient compositions of acha are similar to maize and sorghum (Table 5). A close look at the proximate composition indicates that polished acha contains less crude fibre and more energy compared to maize and sorghum which could be advantageous in feeding of poultry such as chicken. Clottey et al. (2006) reported that acha grains contain greater amounts of most of the essential amino acids than maize (Table 6). Lysine and methionine which are critical amino acids in maize based diets for poultry occur appreciably in acha compared to maize and other cereal grains (Table 6). The level of lysine in acha is similar to that in maize, while methionine content of acha is higher compared to the level in maize.

Table 5: Nutrient composition (\%) of polished acha compared to some cereal grains

\begin{tabular}{lllllllllll}
\hline Nutrients & $\begin{array}{c}\text { Black } \\
\text { acha }\end{array}$ & $\begin{array}{l}\text { White } \\
\text { Acha }\end{array}$ & Maize & Sorghum & Rice & Barley & Rye & Wheat & Millet & Oat \\
\hline Protein & 8.75 & 7.11 & 9.00 & 10.00 & 8.60 & 8.60 & 11.70 & 13.0 & 12.0 & 11.20 \\
Ether extract & 4.00 & 3.00 & 3.90 & 3.00 & 0.40 & 0.40 & 2.0 & 1.50 & 4.0 & 4.50 \\
Fibre & 1.03 & 0.79 & 3.00 & 4.00 & 0.40 & 0.40 & 2.20 & 2.70 & 4.30 & 10.60 \\
Starch & 76.91 & 79.72 & 79.5 & 65.0 & 75.8 & 73.50 & 71.9 & 71.90 & 58.90 & 55.50 \\
Ash & 2.31 & 2.13 & 1.0 & 1.20 & 0.60 & 0.40 & 1.70 & 1.20 & 3.0 & 2.90 \\
Lysine & 1.25 & 1.15 & 0.30 & 0.28 & 0.25 & 0.45 & 0.55 & 0.30 & 0.36 & 0.55 \\
methionine & 0.46 & 0.47 & 0.15 & 0.16 & 0.22 & 0.18 & 0.16 & 0.20 & 0.27 & 0.18 \\
Energy & 3790 & 3740 & 3300 & 2650 & 2990 & 2790 & 2734 & 3060 & 2555 & 2600 \\
(KcalME/Kg) & & & & & & & & & & \\
\hline
\end{tabular}

Source: Lasztity (1999), Idris et al. (2015). 
Importance of acha as a potential feedstuff in Covid-19 era

Table 6: Essential amino acid content of acha compared to maize

\begin{tabular}{lll}
\hline Amino acid & *Acha & $* *$ Maize \\
\hline Threonine & 0.37 & 0.24 \\
Cystine & 0.25 & 0.19 \\
Valine & 0.55 & 0.33 \\
Methionine & 0.45 & 0.17 \\
Isoleucine & 0.40 & 0.23 \\
Leucine & 1.05 & 0.77 \\
Phenylalanine & 0.57 & 0.31 \\
Lysine & 0.25 & 0.23 \\
Tryptophan & 1.60 & 0.06 \\
Tyrosine & 0.35 & 0.00 \\
\hline
\end{tabular}

Sources: GGDP(1993) NRC(1996)

Utilization of Acha as human food and pharmaceutical material

Acha is included in a list of grains considered as whole grains when consumed in whole form (Jideani and Jideani, 2011). According to temple and Bassa (1991) the proteins in these grains are not easily extractable; however, the digestibility of the proteins is better than those of sorghum and millet. It has been reported that diets from acha were tolerated by diabetic patients (Temple and Bassa, 1991). Technologically, acha can be utilized in ways similar to rice. The grains require minimal processing due to grain size and location of constituents and food products from acha are preferred to those from other cereals (McWatters, 2000). Whole acha grains are now used for quick cooking, non-conventional food products including weaning foods of low bulk density and breakfast cereal with good fiber content. The grains could be used in a wide variety of products. Cookies, crackers, and popcorn, made in an almost endless array of forms are examples. Coda et al. (2010) reported that acha flours have potential for sourdough fermentation.

Amidst the growing utilization of the crop as food, it serves as raw material for drug/pharmaceutical industries. Acha (Digitaria exilis) starch has been compared with maize starch as a binder at various concentrations and was found to be as good as maize starch in the formulation of paracetamol tablets (Iwuagwu et al. 2001 and Musa et al.2008).

\section{Utilisation as feed for farm animals}

As stated by Clottey et al. (2006), acha grain with its rich amount of amino acids present in a high protein component for a cereal, acha can be a very good feed source for poultry and pigs. The macro elements, phosphorous and potassium levels, in acha grains can be relied upon to meet the specifications for the formulation of animal diets. Acha grains can provide adequately the trace elements $(\mathrm{Zn}, \mathrm{Cu}, \mathrm{Mn}$ and $\mathrm{Fe})$ needs of monogastric animals (Clottey et $a l ., 2006)$. The straw from the crop is used for stuffing mattresses or as beddings for livestock, hay making, silage, and also serve as good fodder for livestock (Pablo et al., 2003). Recent discoveries revealed that acha is cultivated and used as forage in the Dominican Republic Island of South America (Pablo et al. 2003). Animal study also showed that rats fed with acha-soybean and acha-biscuits had good feed; gain ratio (Ayo et al. 2010).

Constraints to effective production of acha The increasing problem of food insecurity in Africa and the recognition of acha as a potential buffer against famine are expected to stimulate the expansion of land area devoted to acha cultivation in the continent. However, available statistics shows the reduction of acha harvest area in several countries, except in Nigeria, Cote D"Ivoire, and Guinea (Cruz, 2004). In year 2002, a total area of 347,380 hectares was devoted 
to acha production in Africa with Nigeria alone providing almost half of that area (Cruz, 2004). Several factors are responsible for the general decline in acha production, some of which include lodging, small grain size, lower yields than other cereals, shattering and drudgery in postharvest handling especially polishing of the small grains (Cruz, 2004).

A survey of acha production in Nigeria (Kwon-Ndung and Misari, 1999) indicated lack of improved agronomic practices in acha production, especially in the area of weed control. Apart from the general poor husbandry, the husking process of acha grains is very tedious and time-consuming (Kwon-Ndung and Misari, 1999), constituting a major bottleneck in its processing and utilization. Years of research by Non-Governmental Organisations and research institutions have contributed immensely in addressing the husking problem of acha. The breakthrough in acha processing could enhance acha production to meet local demands in Africa and even for export (Aslafy, 2003). This might be responsible for the increased interest in acha production in Africa in recent years. The scientific challenge now is to develop new improved high-yielding and non-shattering varieties of acha with larger grain size shorter and stronger culms and with good grain quality (Kwon-Ndung et al. 2001). Acha grains as feed material for chicken Various reports indicated that acha grains of different species and forms could be used to feed chickens effectively even in the absence of maize in the diet. In broiler chickens, in recent report $100 \%$ percent replacement of maize by polished black acha grains (Table 7) indicated that final live weight and feed consumption were better compared to feeding of whole maize (Ukim et al., 2020). Ukim et al. (2020) also reported that apparent crude protein, starch and crude fibre digestibility (Table 8) generated by $100 \%$ acha was better compared to maize. Adequate protein digestibility would guarantee amino acid availability for metabolic processes and muscle deposit (McNab, 1994). Jideani and Akingbala (1993) and later Ukim et al (2013) reported that improvement of birds on a whole acha grains as major source of energy in substitution for maize grains is an indication that acha grain could be a potential source of energy in broiler diets without compromising productivity. Also Ruskin et al. (1996) recommended acha grains for broiler diets because it is rich in methionine and cysteine which are the limiting amino acids in comparison with maize and other grains. An interesting quality of acha is that it has been reported that feeding of acha to broiler chickens did not impart negatively on the physiological parameters, carcass yield and internal organs of the birds. It was not deleterious on the blood profile (white blood cells, red blood cells, haemoglobin, urea nitrogen, creatinine and liver enzymes), dressing percentage, breast weight percentage, liver

Table 7: Effect of substitution of acha for maize on growth performance of finisher broiler chicks

\begin{tabular}{|c|c|c|c|c|c|c|c|c|c|}
\hline Parameters & $\begin{array}{l}\text { T1 } \\
(0 \%)\end{array}$ & $\begin{array}{l}\text { T2 } \\
(15 \%)\end{array}$ & $\begin{array}{l}\text { T3 } \\
(30 \%)\end{array}$ & $\begin{array}{l}\text { T4 } \\
(45 \%)\end{array}$ & $\begin{array}{l}\text { T5 } \\
(60 \%)\end{array}$ & $\begin{array}{l}\text { T6 } \\
(75 \%)\end{array}$ & $\begin{array}{l}\text { T7 } \\
(90 \%)\end{array}$ & $\begin{array}{l}\text { T8 } \\
(100) \%\end{array}$ & SEM \\
\hline Initial live weight (g) & $1015^{\mathrm{d}}$ & $1022^{d}$ & $1078^{d}$ & $1170^{\mathrm{ab}}$ & $1218^{a}$ & $1135^{b}$ & $1012^{\mathrm{d}}$ & $1095^{\mathrm{b}}$ & 58.80 \\
\hline Final live weight (g) & $2413^{\mathrm{d}}$ & $2577^{\mathrm{c}}$ & $2627^{\mathrm{b}}$ & $2797^{\mathrm{a}}$ & $2737^{\mathrm{a}}$ & $2740^{\mathrm{a}}$ & $2757^{\mathrm{a}}$ & $2633^{\mathrm{b}}$ & 112 \\
\hline Daily weight gain & $49.94^{\mathrm{c}}$ & $55.54^{\mathrm{b}}$ & $55.30^{\mathrm{b}}$ & $58.10^{\mathrm{a}}$ & $54.23^{\mathrm{b}}$ & $57.32^{\mathrm{b}}$ & $55.18^{\mathrm{b}}$ & $54.94^{\mathrm{b}}$ & 3.73 \\
\hline Total feed intake $(\mathrm{g})$ & $4098^{c}$ & $3981^{\mathrm{c}}$ & $4391^{\mathrm{ab}}$ & $4456^{\mathrm{a}}$ & $4334^{b}$ & $4358^{b}$ & $4363^{b}$ & $4423^{\mathrm{a}}$ & 195 \\
\hline Daily feed intake & $146.40^{\mathrm{b}}$ & $142.20^{\mathrm{b}}$ & $157.0^{\mathrm{a}}$ & $159.20^{\mathrm{a}}$ & $154.79^{\mathrm{a}}$ & $155.60^{\mathrm{a}}$ & $156.0^{\mathrm{a}}$ & $158.00^{\mathrm{a}}$ & 6.97 \\
\hline Feed: gain ratio & 2.93 & 2.55 & 2.85 & 2.74 & 2.85 & 2.78 & 2.84 & 2.89 & 0.45 \\
\hline Mortality (\%) & 3.33 & 3.33 & 3.33 & 3.33 & 3.33 & 3.33 & 3.33 & 3.33 & 0.00 \\
\hline
\end{tabular}

Source: Ukim et al. (2020). 


\section{Importance of acha as a potential feedstuff in Covid-19 era}

Table 8: Effect of substitution of acha for maize onapparent nutrient digestibility of broiler chickens

\begin{tabular}{|c|c|c|c|c|c|c|c|c|c|}
\hline $\begin{array}{r}\text { Para } \\
\text { meters }(\%)\end{array}$ & $\begin{array}{l}\text { T1 } \\
(0 \%)\end{array}$ & $\begin{array}{l}\text { T2 } \\
(15 \%)\end{array}$ & $\begin{array}{l}\text { T3 } \\
(30 \%)\end{array}$ & $\begin{array}{l}\text { T4 } \\
(45 \%)\end{array}$ & $\begin{array}{l}\text { T5 } \\
(60 \%)\end{array}$ & $\begin{array}{l}\text { T6 } \\
(75 \%)\end{array}$ & $\begin{array}{l}\text { T7 } \\
(90 \%)\end{array}$ & $\begin{array}{l}\text { T8 } \\
(100) \%\end{array}$ & SEM \\
\hline Dry matter & 90.54 & 90.86 & 90.12 & 91.79 & 91.97 & 92.20 & 92.52 & 92.69 & 4.10 \\
\hline Crude protein & $78.20^{\mathrm{b}}$ & $78.81^{\mathrm{ab}}$ & $79.30^{\mathrm{ab}}$ & $79.63^{\mathrm{ab}}$ & $80.26^{\mathrm{ab}}$ & $80.74^{\mathrm{ab}}$ & $81.48^{\mathrm{a}}$ & $81.84^{\mathrm{a}}$ & 3.16 \\
\hline Crude fibre & $43.66^{\mathrm{d}}$ & $44.53^{\mathrm{d}}$ & $45.32^{\mathrm{d}}$ & $46.04^{\mathrm{c}}$ & $46.88^{\mathrm{bc}}$ & $47.73^{\mathrm{ab}}$ & $48.27^{\mathrm{a}}$ & $48.71^{\mathrm{a}}$ & 1.18 \\
\hline Ash & $68.77^{\mathrm{a}}$ & $68.39^{\mathrm{a}}$ & $67.72^{a}$ & $67.45^{\mathrm{ab}}$ & $67.26^{\mathrm{a}}$ & $66.34^{\mathrm{abc}}$ & $66.34^{\mathrm{abc}}$ & $65.94^{\mathrm{c}}$ & 2.20 \\
\hline Ether extract & $80.56^{\mathrm{a}}$ & $79.88^{\mathrm{a}}$ & $79.53^{\mathrm{ab}}$ & $79.47^{\mathrm{ab}}$ & $78.74^{\mathrm{ab}}$ & $78.49^{\mathrm{ab}}$ & $77.61^{\mathrm{ab}}$ & $76.56^{\mathrm{b}}$ & 3.10 \\
\hline Starch & $76.41^{\mathrm{c}}$ & $76.90^{c}$ & $77.34^{\mathrm{c}}$ & $77.85^{\mathrm{b}}$ & $78.49^{b}$ & $79.67^{\mathrm{ab}}$ & $80.45^{\mathrm{ab}}$ & $81.56^{\mathrm{a}}$ & 3.10 \\
\hline
\end{tabular}

Table 9: Performance of layers fed graded levels of acha in replacement for maize

\begin{tabular}{|c|c|c|c|c|c|c|c|c|c|}
\hline Parameters & $\begin{array}{l}\text { T1 } \\
(0 \%)\end{array}$ & $\begin{array}{l}\text { T2 } \\
(15 \%)\end{array}$ & $\begin{array}{l}\text { T3 } \\
(30 \%)\end{array}$ & $\begin{array}{l}\text { T4 } \\
(45 \%)\end{array}$ & $\begin{array}{l}\text { T5 } \\
(60 \%)\end{array}$ & $\begin{array}{l}\text { T6 } \\
(75 \%)\end{array}$ & $\begin{array}{l}\text { T7 } \\
(90 \%)\end{array}$ & $\begin{array}{l}\text { T8 } \\
(100 \%)\end{array}$ & SEM \\
\hline Total feed intake $(\mathrm{g})$ & 10458 & 10458 & 10458 & 10458 & 10454 & 10440 & 10428 & 10425 & 185.83 \\
\hline Daily feed intake (g) & 124.50 & 124.50 & 124.50 & 124.50 & 124.45 & 124.29 & 124.14 & 124.11 & 2.21 \\
\hline No. of egg laid & $1943^{c}$ & $1912^{\mathrm{c}}$ & $1888^{\mathrm{c}}$ & $2187^{b}$ & $2130^{\mathrm{b}}$ & $2089^{b c}$ & $2433^{\mathrm{a}}$ & $2442^{\mathrm{a}}$ & 77.0 \\
\hline Hen Day $(\%)$ & $68.11^{\mathrm{c}}$ & $65.03^{\mathrm{c}}$ & $64.25^{\mathrm{c}}$ & $74.39^{b}$ & $72.45^{\mathrm{b}}$ & $69.08^{c}$ & $87.77^{\mathrm{a}}$ & $83.06^{\mathrm{a}}$ & 2.99 \\
\hline Feed/dozen egg & $64.59^{\mathrm{a}}$ & $65.64^{\mathrm{a}}$ & $66.47^{\mathrm{a}}$ & $57.38^{\mathrm{b}}$ & $58.90^{\mathrm{b}}$ & $59.97^{\mathrm{b}}$ & $51.43^{\mathrm{c}}$ & $51.23^{\mathrm{c}}$ & 11.40 \\
\hline FCR (feed: egg) & 2.04 & 1.96 & 2.10 & 2.09 & 1.98 & 2.01 & 2.60 & 1.92 & 0.21 \\
\hline
\end{tabular}

and kidney (Ukim, 2018; Ukim et al., 2018). Report also indicated that acha when compared to maize in layers diet produced higher number of eggs laid and hen day. Ukim (2018) observed that when maize was replaced by $100 \%$ acha in layer diet hens on whole acha diet had $83 \%$ hen day compared to maize $63 \%$ even with the same feed intake (Table 9). Ukim et al. (2020) attributed this to higher nutrient digestibility exhibited by acha.

\section{References}

Abdullahi, D. and Luka, D. 2003. The status of acha (Digitaria exilis) production in Bauchi State of Nigeria: Report of the Crop Area Yield (CAY) for year 2003. Presented at the 1st National Acha Stakeholders workshop in Jos, Nigeria.

Anuonye, J. C., Onuh, J. O., Egwim, E. and Adeyemo, S. O. 2010. Nutrient and Antinutrient composition of extruded acha/soyabean blends. Journal of Food Processing and Preservation, 34: 680-691.
Aslafy, J. H. 2003. Organic fonio to woo Europe. Spore 106.

Ayo, J. A., Ikuomola, D. S., Sanni, T. A., Esan, Y. O., Ayo, V. A. and Ajayi, G. 2010. Evaluation of nutritional quality of soybean-acha composite biscuits. Nigerian Food Journal, 28(2):132-138.

Ballogou V. Y., Soumanou M. M., Toukourou F. and Hounhouigan J. D. 2013. Structure and nutritional composition of fonio (Digitaria exilis) grains: A review. International Research Journal of Biological Science, 2(1): 73-79.

Chukwu, O. and Abdul-kadir, A. J. 2008. Proximate chemical composition of Acha (Digitaria exilis and Digitaria iburua) grains. Journal of Food Technology, 6 (5): 214-216.

CIRAD 2004. Centre for international research and development. Fonio: An African cereal crop. www.cirad.frlen. Accessed May 05, 2011.

CIRAD 2006. Centre for international research and development. Research project brings African grain to European tables, 
Ukim, Ndelekwute, Kennedy, Ayuk and Agwunobi

W w w. i n c o-fo n i o-e n cirad.fr/coordination. Accessed May 12, 2010.

Coda, R., Di Cagno, R., Edema, M. O., Nionelli, L. and Gobbetti, M. 2010. Exploitation of acha (Digitaria exilis) and iburu (Digitaria iburua) flours: Chemical characterization and their use for sourdough fermentation: Food Microbiology, 27:1043-105

Clottey, V. A., Avornyo, F., Addo-Kwafo,

A. and Agyare, W. A. 2006. The potential of fonio (Digitaria exilis, Stapf) as feed for monogastrics. Livestock Research for Rural Development. 18 (95). www.lrrd.org/lrrd18/7/clot18095.h tm. Accessed March 14, 2017. .

Cruz J. F., Beavogui F. and Drame, D. 2011. Le fonio, une cereal africaine. Agricutures tropicales en poche. Quae/Cta Presses agronomiques de Gembloux. Versailles, France. 175.

Cruz, J. F. 2004. Fonio: a small grain with potential. LEISA Magazine on low eternal input and sustainable agriculture. LEISA INDIA. $6(1): 1 \quad 6 \quad-117$. www.leisa.info/index.php. Accesseon May 04, 2016.

Dachi, S. N. and Gana, A. S. 2008. Adaptability and evaluation of some acha (Digitaria exilis and Digitaria iburua Kippis Stapf) accessions at Kusogi-Bida, Niger State, Nigeria. African Journal of General Agriculture, 4 (2):73-77.

Dachi, S. N. and Omueti, J.A. I. 2000. The effects of different rates of NPK and organo- mineral fertilizers on the growth and yield of "acha" (Digitaria exilis Kippis Stapf) in South Western Nigeria. Nigerian Journal of Arts, Science and
Technology, 3(1):23-30

Davis, A. J., Dale, N. M. and Rerreira, F. J. 2003. Pearl millet as an alternative feed in broiler chickens diets. Journal of Applied Poultry Research, 12: 137-144

Echendu, C.A., Obizoba, I. C., Anyika, J. U. and Ojimelukwe, P. C. 2009. Changes in chemical composition of treated and untreated hungry rice "Acha" (Digitaria exilis). Pakistan Journal of Nutrition, 8 (11): 17791785.

FAO 2003. Food and Agriculture Organization, Statistics Bulletin. U n i t e d. N a t i o n s . www.faostat.fao.org. Accessed April 14, 2016.

Fliedel G., Ouattara M., Grabulos J., Drame, D. and Cruz J. 2004. Effet du blanchiment mecanique sur la qualite technologique, culinaire et nutritionnelle du fonio. Actes du 2e Atelier international, Ouagadougou, Burkina Faso, 599614.

GGDP 1993. Ghana Grains Development Project. Fifteenth Annual Research Report, Part II, Kumasi, Ghana.

Gyang, J. D. and Wuyep E. O. 2005. Acha: The grain of life. Raw Materials Update. A Bi-annual publication of the Raw Materials Research and Development Council. 6 (1): 39 41.

Ibrahim A. 2001. Hungry Rice (Acha): A neglected cereal crop. NAQAS Newsletter. A quarterly Newsletter of the Nigerian Agricultural Questions and Answer Service ( N A Q A S ). 1 ( 4 ): 4 - 5 . www.http://interships.ctaint/partne rs/naqas/Assets. Accessed on October 04, 2016.

Idris, Z. S., Maiwada S. A., Dauda D., Jamilu Y. M. and Madungurum M. A. 2015. Comparative 


\section{Importance of acha as a potential feedstuff in Covid-19 era}

nutritional analysis of black fonio (Digitaria iburua) and whit fonio (Digitaria exilis). International Research Journal of Biological Sciences, 4(6): 4 - 9.

Jansman, A. J. M, Huisman, J. and Vander Poel, A. F. B 1989. Faba beans with Different tannin contents. Ileal and caecal digestibility in piglets and growth in chickens. In: Recent Advances in Research in Anti-Nutritional factors in legumes seeds (Huisman, J; Vander Poel, A.F.B and I.E. Liener, eds). Poduc, Wageningen, Netherlands, Pp. 176-180.

Iwuagwu, M. A., Onyekweli A. O. and Ob i o r a h B. A. 2001 . Physicochemical properties of paracetamol tablets marketed in Benin City. Nigerian Journal of Pharmaceutical Sciences, 32: 49 51.

Jideani, I. A. and Akingbala, J. O. 1993. Some physicochemical properties of acha (Digitaria exilis and Digitaria iburua). Journal of the Science of Food and Agriculture, 63:369-374.

Jideani, I. A. and Jideani, V. A. 2011. Developments on the cereal grains Digitaria exilis (acha) and Digitaria iburua (iburu), Journal of Food Science and Technology, 48: 251-259.

Knox, A. I. and McNab, J. M. 1995. Selection between high and lowtannin diets by broiler chickens. British Poultry Science, 36: 849 850.

Kwon-Ndung, E. H. and Misari, S. M. 1999. Overview of research and development for fonio (Digitaria exilis Kippis Stapf) and prospect for genetic in Nigeria. In genetic and food security in Nigeria. GNS publication, Nigeria, pp. 76-77.
Kuta, D. D., Kwon-Ndung, E., Dachi, S., Bakare, O. and Ogunkanmi, L. A. 2005. Optimization o f protocols for DNA extraction and PAPD analysis in West African Fonio (Digitaria exilis and Digitaria iburua) germplasm characterization. African Journal ofBiotechnology, 4: 1368 1371.

Kwon-Ndung, E. H., Misari, S. M. and Dachi, S. N. 2001. Study on the production practices of acha (Digitaria exilis Kippis Stapf.) in Nigeria. Science Forum, 4(2):106113.

Ladeji, O., Akin, C. U and Umaru, H. A. 2004. Level of anti-nutritional factors in vegetables commonly eaten in Nigeria. African Journal of Natural Science, 7:71 - 73.

Lasztity, R. 1999. Cereal chemistry. $1^{\text {st }}$ ed. Akademiai Kiado Publishers, Budapest, Hungary. Pp. 112-118.

MacDonald, P., Edwards, R.A. and Greenhalgh, J.F.D. 2000. Animal Nutrition. $5^{\text {th }}$ ed Longman. London. Pp. 56-61.

McNab, J. M. 1994. Amino Acid Digestibility and Availability Studies with Poultry. Farm Animal Nutrition (D'mello J. P. F. ed.), CAB International, UK. Pp. 185 203.

McWatters, K. H., Ouedrago, J. B., Resurreccion, A. V. A., Hung, Y. C. and Phillips, R. D. 2000. Baking performance of wheat, fonio and cowpea flours. Abstract research programs on cowpeas. Dept. of Food Science and Technology, University of Georgia, USA.

Mitaru, B. N., Reichert, R. D. and Blair, R. 1984. The binding of dietary protein by sorghum tannins in the digestive tract of pigs. Journals of 
Ukim, Ndelekwute, Kennedy, Ayuk and Agwunobi

Nutrition 114. Pp. 1787-1796.

Musa, H., Muazu, J. and Bhatia, P. G. 2008. Evaluation of fonio (Digitaria exilis) starch as a binder in paracetamol tablets. Nigerian Journal of Pharmaceutical Sciences.7(1):56-66.

NRC 1996. National Research Council. Lost crops of Africa, Vol. 1, Grains. National Academy Press, USA.

Olomu, J. M. 2011. Monogastric Animal Nutrition, Principles and Practice. $2^{\text {nd }}$ Edition, Jachem Publication, Benin City, Nigeria. pp. 69-104.

Ortiz L. T., Centeno, C. and Trevino, J. 1993. Tannins in faba beans seeds, effects on the digestibility of protein and amino acids in growing chicks. Animal Feed Science and Technology, 41:271-278.

Pablo, J. M., Richard, J. O., Ciero, J. and Taveras, F. 2003. Digitaria exilis as a crop in the Dominican Republic. Trends in New Crops and New Uses, J. Janick and A. Whipkey (eds). Ashs Press, Alexandria, V.A.

Parr, W. H., Capper, B. S., Cox, D. R. S., Jewers, K., Marter, A. D., Nicols, W., Silvey D. R. and Wood J. F. 1988. The small-scall manufacture of compound animal feed. Overseas Development and Natural Resources Institute bulletin. 9(4):87

Philip, T. K. and Isaac N. I. 2012. Demographic characteristics, agricultural and technological profile of acha farmers in Nigeria. Agricultural Engineering International, 14(1): 19-33.

Serna-Saldivar S. O. 2003 . Cereals/Dietary Importance. In: Caballoro B., Trugo L. and Finglas (Eds) Encyclopedia of Food Sciences and Nutrition: Academic Press, London, Pp.1027-1033.
Temple V. J. and Bassa J. D. 1991. Proximate chemical composition of Acha (Digitaria exilis) grain. Journal of the Science of Food and Agriculture, 56: 561-563.

Ukim, C. I., Ojewola, G. S and Obun, C. O. 2013. Nutritive and replacement value of hungry rice "Acha" (Digitaria exilis) grain for maize in broiler starter chicks. Global Journal of Agricultural Science, 12 (1): 55-61.

Ukim, C. I. 2018. Potentials of black acha (digitaria iburua) grains as feed ingredient I chicken diets. A Ph.D dissertation, Department of Animal Science, University of Calabar, Calabar, Nigeria

Ukim, C. I., Agwunobi, L.N., Kennedy Oko, O.O., Ayuk, A.A. and Robert, A. N. 2018. Nutritional Evaluation of Digitaria iburua (Black Acha) grains as feed resource in the diet of Broiler Chickens. Nigerian Journal of Animal Science, 20 (4): 619-630.

Ukim, C.I., Ndelekwute, E.K. and Robert, A. 2020. Effect of substitution of polished whole black Acha for maize on apparent nutrient digestibility and growth performance of broiler chickens. Ec Veterinary Science, 5(12): 4047.

WHO 2019. World Health Organization. Information about Covid-19. www.who.int/emergencies/disease s /novel-coronavirus. Accessed December 22, 2020. 